УДК 378.093.5.011.3-051:796

DOI https://doi.org/10.26661/2663-5925-2021-2-10

\title{
ОЦІНКА ПРОФЕСІЙНОЇ ГОТОВНОСТІ СТУДЕНТІВ ФАКУЛЬТЕТУ ФІЗИЧНОГО ВИХОВАННЯ ДО ПЕДАГОГІЧНОЇ ДІЯЛЬНОСТІ В ЗАКЛАДАХ ЗАГАЛЬНОЇ СЕРЕДНЬОЇ ОСВІТИ
}

\author{
Чиженок Т. М. \\ кандидат біологічних наук, \\ дочент кафедри теорії та методики фізичної культури і спорту \\ Запорізький національний університет \\ вул. Жуковського, 66, Запоріжжя, Украӥна \\ orcid.org/0000-0001-6687-2643 \\ chijiktoma@gmail.com \\ Коваленко Ю. О. \\ кандидат педагогічних наук, \\ доиент кафедри теорії та методики фізичної культури і спорту \\ Запорізький національний університет \\ вул. Жуковського, 66, Запоріжжя, Украӥна \\ orcid.org/0000-0002-0827-9371 \\ visnik_znu@ukr.net
}

Кузьміна Л. I.

кандидат педагогічних наук, дочент кафедри теорії $і$ методики фізичної культури

Білоруський державний педагогічний університет імені Максима Танка

вул. Радянська, 18, Мінськ, Республіка Білорусь

orcid.org/0000-0001-9487-8102

ratushnysn@gmail.com

Ключові слова: професійна

діяльність, структура

діяльності, фахова

підготовка, фізична

культура.
У процесі теоретичного аналізу проблеми встановлено, що одним iз головних завдань сучасної вищої школи України $\epsilon$ забезпечення та набуття студентами знань з фізкультурної галузі, підготовка їх до професійної діяльності в умовах Нової української школи. Провідну роль відіграють та несуть відповідальність заклади вищої освіти 3 підготовки нового покоління педагогів, зміст і рівень кваліфікації яких адекватні інноваціям, що відбуваються в галузі фізичної культури i спорту. Сучасний рівень розвитку суспільства, освіти та науки висуває зовсім нові вимоги до підготовки фахівців, особливо відчутні потреби вдосконалення педагогічної освіти саме фахівців фізкультурної галузі, учителів фізичної культури. Фахівці зазначають, що проблема професійної підготовки майбутніх учителів фізичного виховання в закладах вищої освіти потребує вдосконалення, а в умовах сьогодення ще й швидких змін. Традиційна система освіти не може забезпечити органічне входження нової генерації вчителів у складне та швидкозмінне поле різнопланових потреб навчально-виховної діяльності в сучасній школі. Традиційний зміст, форми та методи підготовки вчителів фізичної культури до професійної діяльності, на жаль, не спроможні будь-що змінити. Реалії підготовки таких фахівців не сприяють формуванню вчителя як активної, творчої особистості, яка сучасно мислить та бере на себе відповідальність за майбутне покоління. Загалом проблема підвищення ефективності професійно-педагогічної підготовки майбутніх учителів фізичного виховання в педагогічних закладах вищої освіти залишається малодослідженою. 
Дане дослідження було спрямоване на аналіз і визначення професійної готовності студентів до педагогічної діяльності в закладах загальної середньої освіти. Було проведено анкетування за двома видами анкет, у результаті якого отримано дані щодо інтересу сучасних студентів до діяльності вчителя фізичної культури та рівня сформованості в них основних компонентів педагогічної діяльності за методикою М.Ф. Матвійчука. У результаті дослідження встановлено, що студенти мають позитивне ставлення до діяльності вчителя фізичної культури, а основним чинником виявлення активності в них $є$ інтерес до засвоєння матеріалу. Сформованість компонентів педагогічної майстерності засвідчує добре володіння комунікативними, конструктивними, руховими й організаторськими здібностями, меншою мірою - гностичними.

\title{
EVALUATION OF PROFESSIONAL PREPAREDNESS OF STUDENTS OF THE FACULTY OF PHYSICAL EDUCATION TO PEDAGOGICAL ACTIVITY IN GENERAL SECONDARY EDUCATION INSTITUTIONS
}

\author{
Chizhenok T. M. \\ Ph. D. (Biological), \\ Assistant Professor at the Department of Theory and Methods \\ of Physical Culture and Sports \\ Zaporizhzhia National University \\ Zhukovsky str., 66, Zaporizhzhia, Ukraine \\ orcid.org/0000-0001-6687-2643 \\ chijiktoma@gmail.com \\ Kovalenko Yu. O. \\ Ph. D. (Pedagogy), \\ Assistant Professor at the Department of Theory and Methods \\ of Physical Culture and Sports \\ Zaporizhzhia National University \\ Zhukovskogo str., 66, Zaporizhzhia, Ukraine \\ orcid.org/orcid.org/0000-0002-0827-9371 \\ visnik_znu@ukr.net
}

Kuzmina L. I.

Ph. D. (Pedagogy),

Assistant Professor at the Department of Theory and Methods of Physical Culture

Belarusian State Pedagogical University named after Maxim Tank

Radyanska str., 18, Minsk, Republic of Belarus

orcid.org/0000-0001-9487-8102

ratushnysn@gmail.com

Key words: professional activity, structure of activity, professional training, physical culture.
In the course of theoretical analysis of the problem, it was established that one of the main tasks of modern higher education in Ukraine is to provide students with knowledge in the field of physical education and prepare them for professional activity in the New Ukrainian School. The leading role and responsibility is played by higher education institutions for the training of a new generation of teachers, the content and level of qualification of which are adequate to the innovations taking place in the field of physical culture and sports. The current level of development of society, education and science puts 
forward completely new requirements for the training of specialists, especially the significant need to improve pedagogical education, namely specialists in the field of physical education, physical education teachers. Experts note that the problem of professional training of future physical education teachers in higher education institutions needs to be improved, and in today's conditions even more rapidly. The traditional education system is unable to provide an organic entry of the new generation of teachers in the complex and rapidly changing field of diverse needs of educational activities in the modern school. The traditional content, forms and methods of training physical education teachers for professional activities, unfortunately, are not able to change anything. The realities of training such specialists do not contribute to the formation of a teacher as an active, creative person who thinks modernly and takes responsibility for future generations. In general, the problem of improving the effectiveness of professional and pedagogical training of future physical education teachers in pedagogical universities remains poorly understood.

This study was aimed at analyzing and determining the professional readiness of students for teaching in general secondary education. A questionnaire was conducted on two types of questionnaires, which resulted in data on the interest of modern students in the activities of physical education teachers and the level of formation of the main components of pedagogical activities according to the method of M.F. Matviychuk. The study found that students have a positive attitude to the activities of physical education teachers, and the main factor in identifying activity in them is the interest in learning the material. The formation of components of pedagogical skills testifies to a good mastery of communicative, constructive, motor and organizational skills, to a lesser extent - gnostic.

Постановка проблеми. Сучасний рівень розвитку суспільства, освіти та науки висуває високі вимоги до підготовки фахівців, що потребує суттєвих змін у професійній підготовці. Особливо відчутні потреби вдосконалення педагогічної освіти, зокрема навчання майбутніх учителів фізичного виховання.

Суспільно-політичні зміни, що відбувалися в Україні, суттєво змінили сутність професійної діяльності вчителів фізичного виховання.

Якщо раніше основною метою підготовки вчителя був технологічний ріст, то сьогодні відбулася переорієнтація на його особистісний розвиток, самоорганізацію й узагальнення діяльнісного й особистісного досвіду. Із цієї позиції професійна готовність розглядається як категорія, яка визначається рівнем професійної освіти, досвідом та індивідуальними здібностями педагога, передбачає, поряд зі технолого-педагогічною готовністю до вирішення професійних завдань, його гуманну педагогічну позицію, ціннісне ставлення до педагогічної діяльності та високий рівень загальної і професійної культури.

Водночас традиційний зміст, форми і методи підготовки вчителів фізичного виховання до професійної діяльності неповністю відповідають вимогам сьогодення, не сприяють формуванню вчителя як активної, творчої особистості. На вищі навчальні заклади покладається відповідальність за підготовку нового покоління педагогів, зміст і рівень кваліфікації яких адекватні інноваціям, що відбувається в галузі фізичної культури і спорту.

Професійне становлення фахівців фізичної культури і спорту досліджували Б.Ф. Курдюков [1], А.Д. Молдован [2], Т.Г. Темерівська [3], Л.П. Сущенко [4], С.В. Переверзєва [5].

Проблеми професійної підготовки вчителів фізичної культури у вищій освіті розробляли Н.I. Степанченко [6; 7], А.А. Проценко [8], Т.Ф. Матвійчук [9].

Загалом проблема підвищення ефективності професійно-педагогічної підготовки майбутніх учителів фізичного виховання у вищих навчальних закладах залишається малодослідженою.

Мета статті - визначення показників готовності студентів факультету фізичного виховання до педагогічної діяльності.

3 метою вирішення поставлених завдань були використані такі методи дослідження:

1. Аналіз і узагальнення літературних джерел.

2. Анкетування. Для дослідження використовували два види анкет. Усі анкети мали інструкцію із заповнення і стосувались таких питань: перша анкета призначалась для визначення у студентів професійного інтересу до діяльності вчителя фізичної культури і включала десять питань. Анкетне опитування дозволяло виявити характер професійного інтересу загалом, а також кожний із компонентів анкети, що особливо важливо у прикладних цілях. 
Заповнення анкет студентами тривало протягом 20-30 хвилин.

Для вирішення другого завдання дослідження студентам пропонувалася анкета для визначення рівня сформованості основних компонентів педагогічної діяльності (організаційні, гностичні, кон-

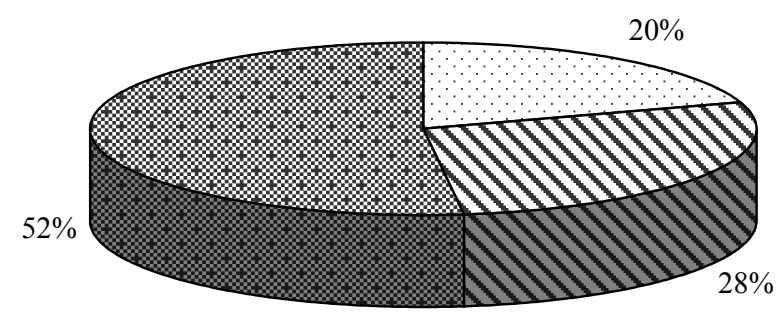

$\checkmark$ дуже подобається

$\checkmark$ переважно так, ніж ні

图 не можу визначитись

\section{Рис. 3.1. Подобається Вам праця вчителя фізичної культури?}

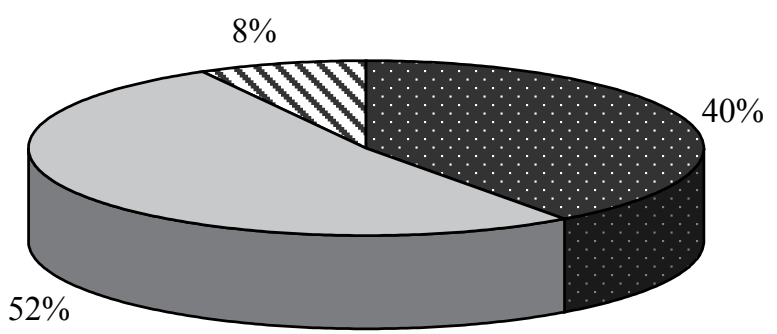

так $\square$ можливо $\mathbf{\nabla}$ незнаю

Рис. 3.2. Як би Вам знову довелось вибирати, чи поступили б на факультет фізичного виховання?

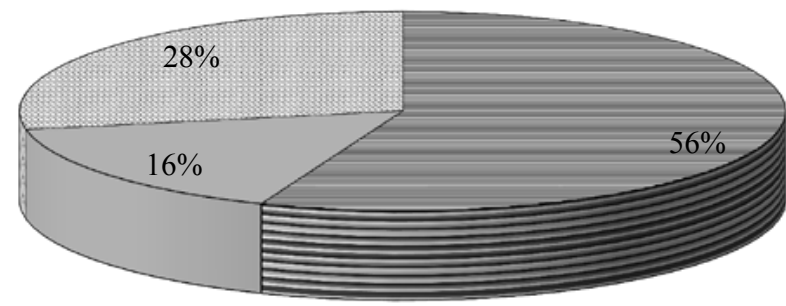

छподобалось і раніше

$\square$ не зробило повністю привабливою

๑ почав сумніватися у процесі навчання

Рис. 3.3. Як змінилось Ваше ставлення до діяльності вчителя фізичної культури у процесі навчання у виші? структивні, комунікативні, рухові) за методикою Т.Ф. Матвійчук (2015р.) [9].

3. Стандартні методи математичної статистики.

Дослідження проводилось на факультеті фізичного виховання Запорізького національного університету зі студентами четвертого курсу денного відділення спеціальності 017 «Фізична культура i спорт» напряму підготовки «фізичне виховання».

Виклад основного матеріалу. Аналіз діагностики визначення наявності професійного інтересу до педагогічної діяльності вчителя фізичної культури дозволив виявити характер професійного інтересу загалом, а також кожного компонента (емоційний, мотиваційний, інтелектуальний та вольовий).

Професійний інтерес до педагогічної діяльності здійснюється послідовним вивченням його структурних компонентів. За даними, вплив зовнішніх умов на суб'єкта визиває прояв емоцій до обраної професії. Після чого відбувається обгрунтування вибору професії і формуються мотиви цього вибору. Сформовані мотиви впливають на прояв інтелектуальної і вольової активності, спрямованої на засвоєння професії.

У результаті аналізу питань анкетного опитування були отримані такі дані. Виявлено, що більшість 3 опитуваних студентів (52\%) не можуть визначитися, подобається їм робота вчителя фізичної культури чи ні; 28\% уважають, що робота вчителя фізичної культури радше подобається. I тільки $20 \%$ студентів упевнені, що робота вчителя дуже подобається (рис. 3.1).

Як би студентам довелось знову поступати на факультет фізичного виховання, то $40 \%$ стверджують, що вони би поступили на навчання, 52\% студентів відповіли - «можливо», $8 \%$ не знають, тобто не змогли визначитися (рис. 3.2).

Щодо питання, чи змінилось ставлення до діяльності вчителя протягом навчання, у більшості студентів (56\%) у процесі навчання у виші покращилось ставлення до діяльності вчителя фізичної культури, вона стала більш привабливою, інші студенти (28\%) уважають, що процес навчання змусив їх сумніватися у вибраній професії, менша кількість студентів (16\%) стверджують, що процес навчання не зробив професію привабливою (рис. 3.3).

На питання, що вплинуло на вибір професії, спрямованої на фізичну та спортивну діяльність, отримано відповіді, що в більшості студентів $(60 \%)$ це був інтерес до фізкультурно-спортивної діяльності (у спортивних секціях, клубах, ДЮСШ); 24\% студентів уважають, що на них вплинув інтерес до діяльності вчителя фізичної культури, тільки $16 \%$ респондентів відповіли, що у виборі цієї професії прислухались до рекомендацій учителів, друзів, батьків (рис. 3.4). 
Аналіз анкетних даних також показав, що найбільше приваблює в діяльності вчителя фізичної культури в основному робота 3 дітьми шкільного віку й отримані результати навчання (48\%); усі види діяльності вчителя подобаються 28\% студентів, 24\% подобаються оптимальні умови праці (рис. 3.5).

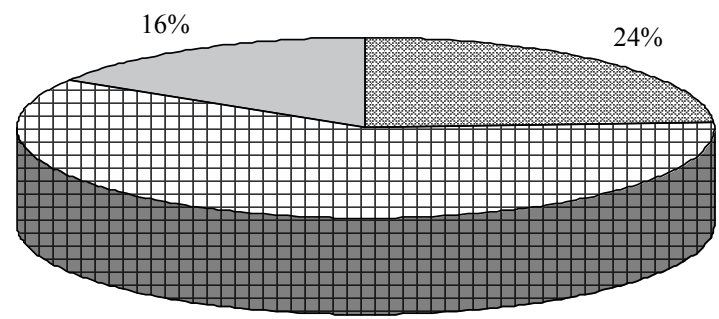

$60 \%$

图 інтерес до діяльності вчителя

田 інтерес до фізкультурно-спортивної діяльності

$\square$ рекомендації вчителя, батьків, друзів

Рис. 3.4. Що вплинуло на вибір професії вчителя фізичної культури і спорту?

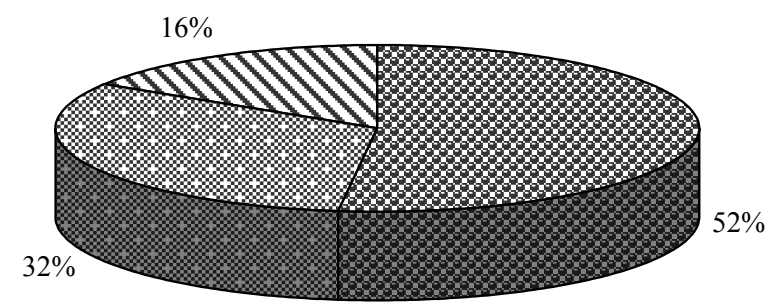

图 від професійної придатності, здібностей та психофізичних можливостей

图 від наявності матеріально-технічної бази

\від прояву вольових зусиль, витримки, терпіння

Рис. 3.6. Від чого залежить ефективність педагогічної діяльності вчителя?

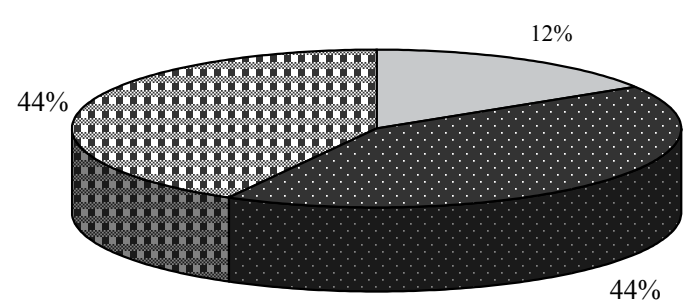

$\square$ регулярно, бо це необхідно

四 іноді, якщо цього вимагає викладач

圆 у разі питання $є$ цікавим для мене

Рис. 3.8. Наскільки Ви регулярно вивчасте додаткову літературу 3 фізичного виховання школярів?
Аналіз відповідей студентів на питання, від чого залежить ефективність педагогічної діяльності вчителя фізичної культури, показав, що $52 \%$ уважають, що від професійної придатності, здібностей та психофізичних можливостей; $32 \%$ від наявності матеріально-технічної бази у школі, $16 \%$ студентів упевнені в тому, що від вольових

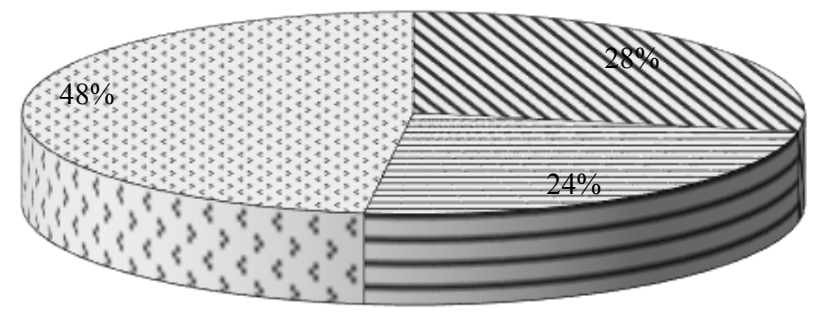

四сі види діяльності вчителя

Ө оптимальні умови праці

ㅁпраця з дітьми шкільного віку і результат

Рис. 3.5. Що більш за все приваблює Вас у діяльності вчителя фізичної культури?

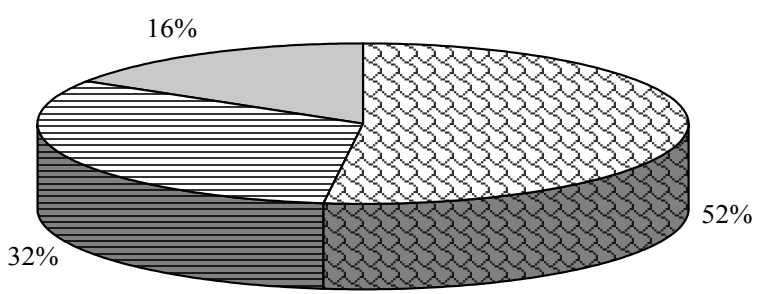

口 набуття та удосконалення нових умінь, навичок у методиці організації процесу навчання

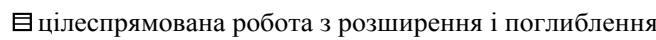
теоретичних знань

$\square$ придбання знань, вмінь, навичок, якостей учителя, які мені подобаються

Рис. 3.7. 3 якими судженнями про підготовленість більш за все Ви згодні?

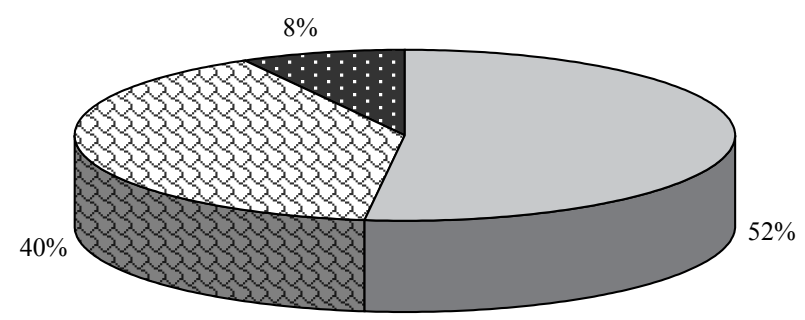

$\square$ всюди і завжди прилагаю максимум зусиль до занять прилагаю зусилля там де цікаво

由 не можу заставити себе

Рис. 3.9. Якою мірою Ви проявлясте вольову активність в опануванні знань, умінь, навичок? 


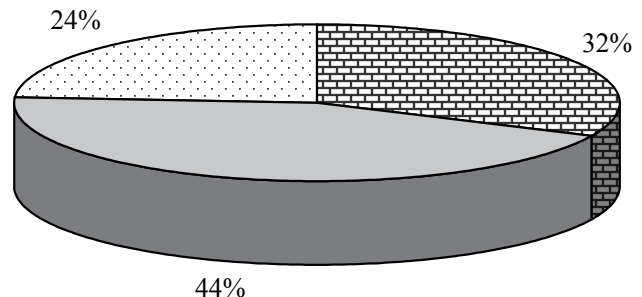

固заняття не пропускаю без поважних причин

$\square$ не пропускаю заняття, це мені цікаво

$\square$ не пропускаю, бо це вимоги навчання (деканату, кафедри)

Рис. 3.10. Як часто Ви пропускаєте заняття?

зусиль, витримки та терпіння під час проведення навчально-виховного процесу (рис. 3.6).

Аналіз суджень студентів о професійній підготовленості показав, що $52 \%$ студентів згодні з тим, що більш за все це опанування й удосконалення нових знань, умінь навичок у методиці організації процесу навчання, $32 \%$ студентів уважають, що це цілеспрямована робота з розширення і погли-

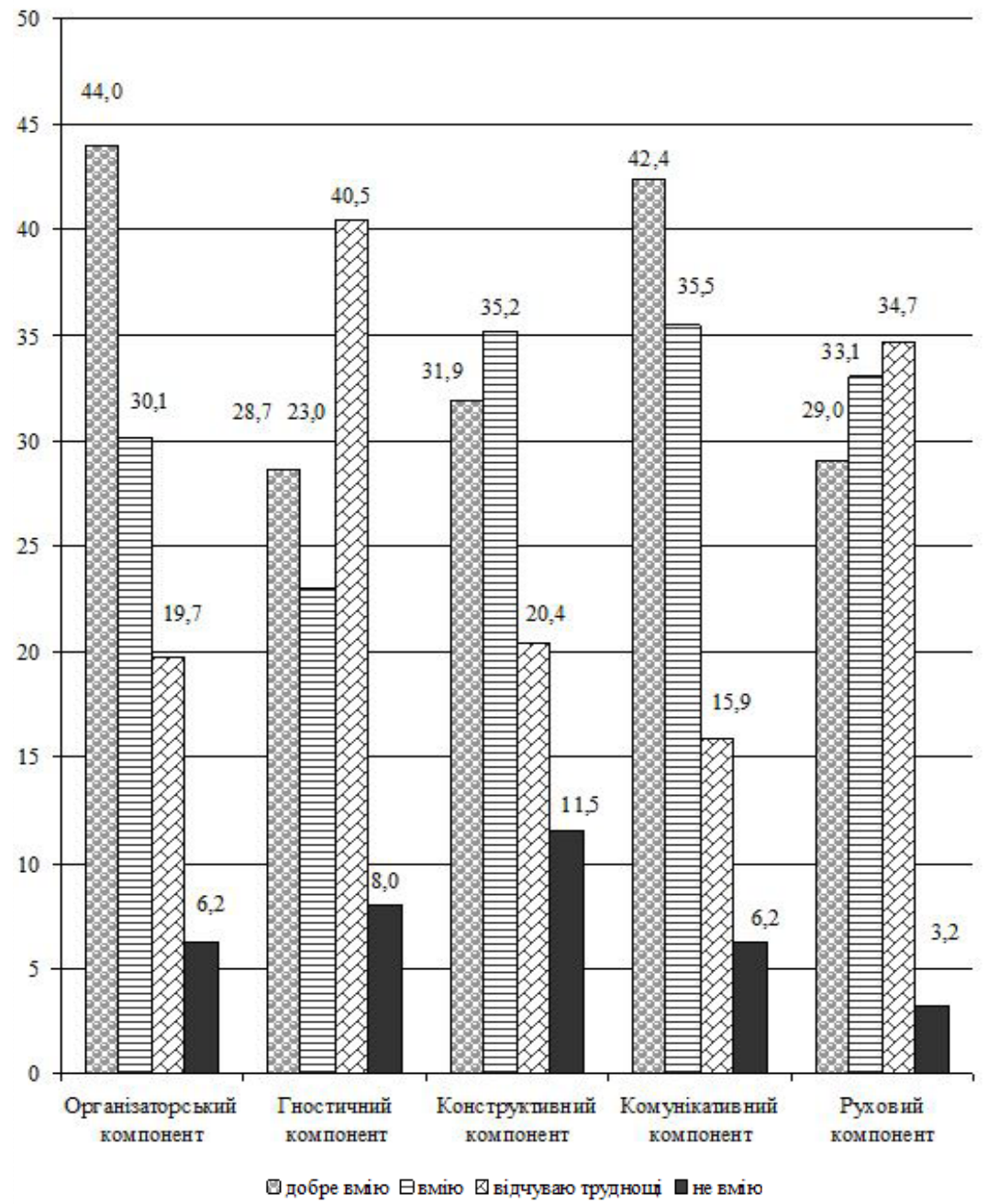

Рис. 3.11. Самооцінка сформованості педагогічних умінь студентами блення теоретичних знань, тільки $16 \%$ стверджують, що це здобуття знань, умінь, навичок, якостей учителя фізичної культури, які подобаються (рис. 3.7).

Аналіз відповідей студентів щодо вивчення додаткової літератури 3 фізичного виховання учнів показав, що тільки $12 \%$ регулярно використовують додаткову літератури 3 фізичного виховання; 44\% - якщо цього вимагає викладач, $44 \%$ - у разі, коли будь-яке питання буде цікавим для них (рис. 3.8).

Найбільший відсоток відповідей студентів (52\%) ми отримали щодо прояву їхньої вольової активності в опануванні професійної діяльності, 40\% студентів вольову активність проявляють лише там, де їм цікаво, і не можуть змусити себе вчасно підготуватись до заняття, заліку або екзамену; $8 \%$ студентів не можуть змусити себе постійно навчатися, часто бувають не готові до навчання (рис. 3.9).

На питання анкети «Як часто Ви пропускаєте заняття?» 32\% відповіли, що заняття не пропускають без поважних причин і вважають, що здобувають нові й потрібні знання, 44\% студентів не пропускають лише ті заняття, які їм цікаві, 24\% відвідують заняття на факультеті, бо це вимоги навчання, деканату, кафедри (рис. 3.10).

Отже, за результатами проведеного опитування студентів вищого навчального закладу видно, що у студентів сформувалось позитивне ставлення до педагогічної діяльності, про що свідчить більший відсоток відповідей $(56 \%)$, але треба відзначити, що необхідну додаткову літературу вивчають тільки тоді, коли цього вимагає викладач і коли це питання є цікавим для студентів (88\%), тільки $32 \%$ студентів відвідують усі заняття, бо вважають це за необхідне для діяльності. Усе це свідчить про те, що студенти слабо мотивовані до навчальної діяльності, докладають не досить зусиль, щоб успішно опанувати педагогічну професію вчителя фізичної культури.

3 метою виявлення реального стану формування педагогічної майстерності в майбутніх фахівців фізичної культури вивчався ступінь сформованості компонентів педагогічної майстерності у студентів факультету фізичного виховання. 
На основі отриманих даних можна стверджувати, що більшість студентів уважають, що вміють організовувати колективну діяльність учнів і педагогічний процес загалом (74,1\% дали відповідь «добре вмію» або «вмію»), але 19,7\% водночас відчувають труднощі в організації, а $6,2 \%$ студентів не володіють організаційним компонентом і вважають, що ця діяльність для них заважка (рис. 3.11).

Гностичні вміння є одними 3 основних у процесі становлення майбутнього вчителя, професіонала у своїй діяльності, тому що визначають діяльність, її ефективність і подальший процес самовдосконалення.

За даними анкети, приблизно 48,5\% студентів мають слабку гностичну компетентність (пізнавальну) чи не мають iï в галузі методики викладання дисципліни, високий рівень володіння знаннями із психолого-педагогічного циклу. Цей факт можна пояснити відсутністю педагогічного досвіду, невмінням себе об'єктивно оцінити й аналізувати власну діяльність.

Конструктивний компонент відзначається тим, що фахівець правильно визначає зміст навчального матеріалу 3 урахуванням цілей i завдань уроку; формує в учнів систему знань і умінь; добирає необхідні методи і засоби навчання.

На основі аналізу отриманих анкетних даних із конструктивних умінь зазначимо, що приблизно $68,1 \%$ студентів добре вміють або просто вміють планувати навчально-виховний процес учнів i власну діяльність. Але $31,9 \%$ студентів відзначають труднощі 20,4\% із них не вміють планувати рухові дії учнів з метою їхнього фізичного вдосконалення (рис. 3.11). Комунікативний компонент свідчить, що навчальна діяльність є спільною діяльністю учителя й учнів. До комунікативних здібностей належить здатність фахівця встановлювати оптимальні взаємини з учнями, перебудовувати їх відповідно до розвитку учнів на основі морально-етичних вимог до діяльності педагога.

На основі отриманих даних видно, що аналізувати педагогічну ситуацію, налагоджувати комунікативні стосунки 3 учнями, планувати виховну роботу «добре вміють» - 42,4\% студентів, «уміють» $-35,5 \%$.

Із труднощами стикаються $15,9 \%$ респондентів, 6,2\% - у виконанні комунікативної діяльності (рис. 3.11).

Актуальність сформованості рухового компонента, який включає кваліфікаційне володіння на належному рівні технікою фізичних вправ, як мінімум в обсязі шкільної програми 3 фізичної культури, і здійснення якісного показу вправ, окремих елементів; уміння вибирати правильне місце для показу і своєчасно застосувати страхування учнів на спортивному обладнані, свідчить про те, що 29,0\% студентів добре володіють руховим компонентом, $33,1 \%$ - уміють виконувати i володіють на належному рівні прикладними навичками (ремонт інвентарю, туристичного спорядження, підготовка майданчиків для ігор тощо). $3,2 \%$ студентів уважають, що деякі вміння рухового компонента $є$ для них важкими (рис. 3.11).

Отже, на підставі отриманих анкетних даних можна вважати, що наявна система формування основних компонентів структури професійної діяльності майбутніх учителів фізичної культури потребує вдосконалення, додавання деяких заходів у процес навчання і навчальні програми підготовки бакалаврів.

Результати анкетування студентів зі сформованості професійно-педагогічних умінь виявили різний рівень у майбутніх учителів фізичної культури. Студенти добре володіють комунікативним компонентом (77,9\%), менше організаторськими $(74,1 \%)$, конструктивним $(68,1 \%)$ та руховим $(62,1 \%)$, найменше володіють гностичним компонентом $(51,5 \%)$.

Висновки. На основі аналізу науково-методичної літератури можна стверджувати, що навчально-професійна підготовка $є$ провідною діяльністю студентів, у процесі якої відбуваються особистісне зростання, професійний розвиток, набуття професійно важливих знань, умінь і навичок.

Вивчення наявності у студентів факультету фізичного виховання професійного інтересу до діяльності вчителя фізичної культури показало, що загалом студенти мають позитивне ставлення до діяльності вчителя фізичної культури; основними чинниками проявлення активності студентів $€$ необхідність вчасно складати залік або екзамен, особистісний інтерес до засвоєння будьякого матеріалу, вимоги педагога до вивчення даного навчального матеріалу.

Стан сформованості компонентів педагогічної майстерності студентів мав такий вигляд: $77,9 \%$ студентів добре володіють комунікативним компонентом, менше організаторським $(74,1 \%)$, конструктивним $(68,1 \%)$ та руховим компонентами $(62,1 \%)$, найменше володіють гностичною компетентністю 3 методики викладання і рівня володіння знаннями 3 дисциплін педагогічного циклу $(51,5 \%)$.

\section{ЛІТЕРАТУРА}

1. Курдюков Б.Ф. Теория и методика модернизации процесса профессиональной подготовки физической культуры в системе высшего образования. Краснодар, 2004. 303 с.

2. Молдован А.Д. Проблеми підготовки майбутніх фахівців фізичної культури та спорту до професійної діяльності у вищих навчальних закладах. Молодий вчений. 2017. № 3. С. 213-217. 
3. Темерівська Т.Г. Стан готовності студентів факультету фізичної культури та здоров'я людини до майбутньої професійної діяльності. Проблеми фізичного виховання і спорту. 2010. № 11. С. 123-124.

4. Сущенко Л.П. Професійна підготовка майбутніх фахівців фізичного виховання та спорту. Педагогіка : наукові праці. 2000. Т. 7. С. 122-126.

5. Переверзєва С.В. Формування готовності майбутніх учителів фізичної культури до професійного саморозвитку. Педагогіка вищої та середньої освіти. 2017. № 1. С. 56-66.

6. Степанченко Н.І. Система професійної підготовки майбутніх учителів фізичного виховання у вищих навчальних закладах : автореф. дис. ... докт. пед. наук. Вінниця, 2017. 29 с.

7. Степанченко Н.І. Концепція професійної підготовки майбутніх учителів фізичного виховання. Львів : ДРУКАРТ, 2017. 42 с.

8. Проценко А.А. Система професійної підготовки сучасного вчителя фізичної культури. Теоретико-методичні засади підготовки майбутнього фахівия з фізичного виховання, спорту та здоров'я людини. 2017. С. 86-90.

9. Матвійчук Т.Ф. Формування педагогічної майстерності майбутніх учителів фізичного виховання у процесі професійної підготовки. Вінниця : Полісся, 2015. 272 с.

\section{REFERENCES}

1. Kurdyukov B.F. (2004) Teoryya y metodyka modernyzatsyy protsessa professyonal'noy podhotovky fyzycheskoy kul'tury v systeme vyssheho obrazovanyya [Theory and methods of modernization of the process of professional training of physical culture in the system of higher education]. Krasnodar. $303 \mathrm{p}$.

2. Moldovan A.D. (2017) Problemy pidhotovky maybutnikh fakhivtsiv fizychnoyi kul'tury ta sportu do profesiynoyi diyal'nosti u vyshchykh navchal'nykh zakladakh [Problems of training future specialists in physical culture and sports for professional activity in higher educational institutions]. Molodyy vchenyy. № 3. S. 213-217.

3. Temerivs'ka T.H. (2010) Stan hotovnosti studentiv fakul'tetu fizychnoyi kul'tury ta zdorov'ya lyudyny do maybutn'oyi profesiynoyi diyal'nosti. [The state of readiness of students of the Faculty of Physical Culture and Human Health for future professional activity]. Problemy fizychnoho vykhovannya $i$ sportu. № 11. S. $123-124$.

4. Sushchenko L.P. (2000) Profesiyna pidhotovka maybutnikh fakhivtsiv fizychnoho vykhovannya ta sportu. [Professional training of future specialists in physical education and sports]. Pedahohika Naukovi pratsi. T. 7. S. $122-126$.

5. Pereverzyeva S. (2017) Formuvannya hotovnosti maybutnikh uchyteliv fizychnoyi kul'tury do profesiynoho samorozvytku. [Formation of readiness of future teachers of physical culture for professional self-development]. Pedahohika vyshchoyi ta seredn 'oyi osvity. № 1. S. 56-66.

6. Stepanchenko N.I. (2017) Systema profesiynoyi pidhotovky maybutnikh uchyteliv fizychnoho vykhovannya u vyshchykh navchal'nykh zakladakh [The system of professional training of future teachers of physical education in higher education] : avtor. dok. ped. nauk. Vinnytsya. $29 \mathrm{~s}$.

7. Stepanchenko N.I. (2017) Kontseptsiya profesiynoyi pidhotovky maybutnikh uchyteliv fizychnoho vykhovannya. [The concept of professional training of future teachers of physical education]. L'viv : DRUKART. $42 \mathrm{~s}$.

8. Protsenko A.A. (2017) Systema profesiynoyi pidhotovky suchasnoho vchytelya fizychnoyi kul'tury. [The system of professional training of a modern teacher of physical culture]. Teoretyko-metodychni zasady pidhotovky maybutn'oho fakhivtsya z fizychnoho vykhovannya, sportu ta zdorov'ya lyudyny. S. 86-90.

9. Matviychuk T.F. (2015) Formuvannya pedahohichnoyi maysternosti maybutnikh uchyteliv fizychnoho vykhovannya u protsesi profesiynoyi pidhotovky [Formation of pedagogical skills of future physical education teachers in the process of professional training]. Vinnytsya : Polissya. $272 \mathrm{~s}$. 